EL MUHASABA: Jurnal Akuntansi (e-Journal)

Volume 10 , No. 2, Tahun 2019

P ISSN: 2086-1249 ; E ISSN: 2442-8922

\title{
COMPANY SIZE STRENGTHENS THE INFLUENCE OF ASSET STRUCTURE AND CAPITAL STRUCTURE ON FIRM VALUE
}

\author{
Supami Wahyu Setiyowati \\ Universitas Kanjuruuhan, Jl. S. Supriadi No. 48 Malang, 65148, Indonesia \\ e-mail : setiyo@unikama.ac.id \\ Mardiana \\ Universitas Islam Negeri Maulana Malik Ibrahim Malang, JL. Gajayana No. 50 \\ Malang, 65144, Indonesia \\ e-mail :mardiana@uin-malang.ac.id
}

\begin{abstract}
This study discusses the size of the firm that is approved by the asset structure and capital structure of firm value. This research is a quantitative study. The analysis technique used is Multiple Regression Analysis (MRA). The results of this study find facts about firm that manage the relationship of assets and capital structure to the value of the firm. Partially, the size of the company increases the asset structure against the value of the firm. The size of the firm is not in accordance with the firm structure of firm value. In conclusion, the size of the firm increases the use of assets in increasing the value of the firm.
\end{abstract}

Keywords : Asset Structure, Capital Structure, firm Value, firm Size

\section{Abstrak}

Studi ini meneliti tentang ukuran perusahaan memperkuat pengaruh struktur asset dan struktur modal terhadap nilai perusahaan. Penelitian ini merupakan penelitian kuantitatif. Teknik analisis yang digunakan adalah Multiple Regresi Analisis (MRA). Hasil penelitian ini menemukan bahwa secara simultan ukuran perusahaan memperkuat hubungan struktur asset dan struktur modal terhadap nilai perusahaan. Secara parsial ukuran perusahaan memperkuat pengaruh struktur asset terhadap nilai perusahaan. Ukuran perusahaan tidak memperkuat pengaruh struktur modal terhadap nilai perusahaan. Kesimpulannya, ukuran perusahaan memperkuat penggunaan struktur asset dalam meningkatkan nilai perusahaan.

Kata kunci: Struktur Aset, Struktur Modal, Nilai Perusahaan, Ukuran Perusahaan 
Supami Wahyu Setiyowati dan Mardiana : Company Size Strengthens The Infuence of Asset Structure and Capital Structure on Firm Value

\section{PRELIMINARY}

Competition in the business world is increasing in the era of industrial revolution 4.0. All companies in the world have no distance in competing to attract investors and potential investors. The goal is to establish a company to maximize profits to increase company value. The development of the company requires large funds as capital.

The decision to invest in a company is determined by the value of the company. To attract prospective corporate investors must be able to maximize the value of the company. The value of the company reflects the current intristic value and reflects the prospects and expectations of the company's ability to increase wealth value in the future, (Silaban, 2013).

According to Nyamasege (2014) Asset structure is a factor that influences company value. The fixed asset structure determines the value of the company. Companies that have large fixed assets usually have stable finance. Companies that utilize assets optimally will have an impact on increasing returns. Increasing returns will increase the value of the company. Research on the structure of assets to the value of the company has been carried out by Mandalika (2016) which shows that structure has no effect from the asset structure to the value of the company.

Capital structure is a factor that influences company value. Capital structure is a collection of funds that can be used and allocated by the company. Collection of funds comes from long-term debt and own capital. Companies that have a bad capital structure are companies that have large debts which result in a heavy burden on the company (Nadzirah, 2016). The results of the research by Dewi, et al. (2003) found that the capital structure has a negative and significant influence on firm value. Abidin, et al (2014), show that the capital structure has a positive and significant effect on firm value.

Company size is an indicator that shows the company's financial strength. The larger the size of the company, the easier it is to obtain funds from both internal and external. Smooth funding will increase the value of the company. Company size has a positive effect on firm value, (Soliha and Taswan, 2002. 
Large companies have wider access than small companies. In addition, the greater the company, the greater investor confidence in the return on investment. Large companies tend to provide greater operating results so as to provide a more favorable return than smaller companies.

The results of previous studies were inconsistent, the researchers added one more variable, namely company size as a moderating variable. This research is to test whether the size of the company is able to moderate the relationship of asset structure and capital structure to the value of food and beverage companies listed on the Indonesia Stock Exchange for the period 2013-2017. The purpose of this study is to examine the effect of asset structure and capital structure on firm value in moderating company size.

\section{LITERATURE REVIEW}

\section{Company Value (CV)}

The purpose of establishing a company is to get the maximum profit, because with large profits it is expected to be able to prosper shareholders and attract investors to invest in the company. The task of financial managers maximizing the value of the company is to maximize the value of the company's shares which will automatically affect shareholders' welfare, (Kasmir, 2010). According to Martono and Harjito (2002) states that companies obtain maximum profit for the prosperity of company owners and maintain the survival of the company will impact the welfare of the wider community outside the company as corporate social responsibility. This is a management achievement in managing the company.

The company value is measured using PBV (Price Book Value) in this study. PBV is a market ratio used to measure the performance of stock market prices on book value. PBV (Price Book Value) is a factor that is considered by an investor in determining which shares to buy. PBV (Price Book Value) is the company's ability to create corporate value in the form of prices on available capital. The higher PBV (Price Book Value) means the company can be said to succeed in creating value and prosperity of the owner. 


\section{Asset Strukture (AS)}

Asset structure is defined as the composition of company assets used to determine how much funds in each component of assets consist of fixed assets and current assets. Asset structure is a comparison between the size of the company's fixed assets and total assets

The asset structure in this study is projected by Fixed Assets (FA) or fixed assets which are used as collateral to meet the needs of the Company. Asset structure describes the proportion between total assets and company fixed assets. Because companies that have large fixed assets will find it easier to obtain capital from outside parties.

The composition of fixed assets determines the value of a particular company. Most stable financial companies have the highest investment value in terms of fixed assets. When these assets are utilized optimally by competent staff, this will increase the company's return and ultimately affect the growth of company value (Nyamasege et.al, 2014)

\section{Capital Structure (CS)}

The optimal capital structure is a capital structure that can minimize the use of overall capital costs. Companies that can minimize the use of capital costs will increase the value of the company. The growth or development of the company uses its own capital derived from share capital, retained earnings and reserves. If the capital is still lacking, it is necessary to consider borrowing capital from outside in the form of debt. According to Halim, (2015) capital structure is the ratio of total debt (foreign capital) to total equity / equity. The capital structure in this study is Debt to Equity Ratio DER is a ratio that measures the amount of debt that can be covered by own capital (Kasmir, 2010)

\section{Company Size (CS)}

Company size is grouping companies into several groups, including large, medium and small companies. Company scale is a measure used to reflect the size of the company based on the company's total assets (Suwito and Herawaty, 2005) 
Company size is a company scale that is seen from the total assets of the company at the end of the year. Total sales can also be used to measure the size of the company (Veronica and Siddharta, 2005). The size of the company describes the size of the company. The size of the business is reviewed from the business field undertaken. Determination of the scale of the company can be determined based on total sales, total assets, average sales level (Seftianne,2011)

\section{HYPOTHESIS}

Firm size strengthens the effect of asset structure and capital structure on firm value

Assets are assets owned by the company. The source of assets comes from the owner of the company. The asset structure describes the amount of assets owned by the company (Jusup, 2011). Optimal use of assets by competent human resources will increase the value of the company. This statement is reinforced by research conducted by Pridadi (2018) which states that the asset structure affects the value of the company.

Capital structure is the ratio between total debt (foreign capital) and total equity / equity (Halim, 2015). The higher the proportion of debt, the higher the value of the company. This shows that the company is able to utilize debt for optimal company operations.

The larger the size of the company, the greater the tendency to use foreign capital. This is because large companies need large funds to support their operations, and one alternative is to fulfill it with foreign capital if their own capital is insufficient (Halim, 2015). Febrianti (2012) concluded that the size of the company has an influence on the value of the company. The larger the size of the company, the value of the company increases. Based on the above, the hypothesis proposed is as follows

H1: It is assumed that company size strengthens the effect of asset structure and capital structure on firm value

\section{Company size strengthens the effect of the asset structure on firm value}

Total assets owned by the company, which can be used for company operations. Company assets that are used optimally based on company size will 
further increase the value of the company. Companies that have large sizes have broad access to market their products. The results of the sale of these products will increase the company's profits so that the company's value also increases. Based on the above, the hypothesis proposed is as follows:

$\mathrm{H} 2$ : It is assumed that company size strengthens the effect of the asset structure on firm value

The size of the company strengthens the influence of the capital structure on firm value

The larger the size of the company, then there is a tendency for more investors to pay attention to the company. This is because large companies tend to have more stable conditions. The stability attracted investors to own the company's shares (Halim, 2015)

The increase in profits obtained by the company from the use of debt increases the value of the company. Chowdhury and Clowdhury (2010) who concluded that capital structure has a significant effect on firm value, because by changing the composition of the company's capital structure can increase company value. While the research of Dewi, et al (2013) shows that the Capital Structure has a negative and significant effect on firm value. Based on the above, the proposed hypothesis is as follows:

H3: It is assumed that company size strengthens the effect of capital structure on firm value

\section{RESEARCH METHODOLOGY}

\section{Types of Research}

This type of research is explanatory. This type of research explains the causal relationship between variables and their effects through hypothesis testing. Testing this hypothesis explains phenomena in the form of relationships between variables,(Indriantoro and Supomo, 2002).

\section{Population and Sampling Procedures}

The population used in this study were food and beverage companies listed on the Indonesia Stock Exchange. The period of research observation was 
carried out from 2013 to 2017. The research samples were 55 companies. The company that is the sample in this study was chosen based on certain criteria (purposive sampling).

\section{Types and Data Sources}

The data used in this study is secondary data taken from the company's annual report. Secondary data was obtained from the Indonesia Stock Exchange investment gallery Faculty of Economics and Business, Kanjururan University, Malang. The technical analysis of the data used in this study is using Multiple Regression analysis (MRA).

\section{RESEARCH RESULTS AND DISCUSSION}

\section{Test classic assumptions}

The results of the normality test using the Kolmogorov Smirnov test are asymp values. sig (2-tailed 0.06 is greater than 0.05 . In conclusion, the data in this study are normally distributed. Multicollinear test using VIF (Variance Inflation Factor). VIF value is smaller than 10. The conclusion of the research data is that there is no multicollinearity.

Test heteroskedastistas using the Glejser test. Significance value greater than 0.05 . In conclusion, the data in this study did not occur heteroscedasticity. Autocorrelation test using collapse test. Sig (2-tailed) value is greater than 0.05 . In conclusion, the data in this study did not occur autocorrelation.

\section{Hypothesis Testing Results}

Table 1.Multiple regression analysis test results

\begin{tabular}{|l|l|l|l|}
\hline Variable & T count & significance & Description \\
\hline AS $^{*}$ CS & 2.521 & 0.015 & accepted, \\
\hline CS ${ }^{*}$ CS & 1.915 & 0.061 & rejected \\
\hline F test 10.281 sig 0.000 & \\
\hline
\end{tabular}

Data sources are processed in 2018

1. The result of the $F$ test is 10.281 with a significance of 0.000 , the significance value is less than 0.05 . This result shows that the first 
hypothesis is accepted. Firm size is proven to moderate the relationship of asset structure and capital structure to firm value

2. The results of the $\mathrm{T}$ test count 2.521 with a significance of 0.015 , a significance value of less than 0.05 . That is the second hypothesis accepted. The size of the company has proven to be able to strengthen the influence of the asset structure on firm value

3. The results of the $\mathrm{T}$ calculation are 1.915 with a significance value of 0.061 greater than 0.05 . this result shows that the third hypothesis is rejected. Company size is not proven to strengthen the influence of capital structure on firm value.

\section{Discussion}

Firm size strengthens the effect of asset structure and capital structure on firm value

Company size strengthens the influence of asset structure and capital structure on firm value. According to Nyamasege, (2014) the composition of fixed assets determines the value of a particular company. Companies that have high investment in fixed assets. The company will increase the value of the company. Large companies tend to have more flexible funding sources, so they will increase their debt to maximize the capital structure to increase company value.

\section{Company size strengthens the effect of the asset structure on firm value}

The results of this study indicate that the size of the company strengthens the influence of asset structure on firm value. Companies in Indonesia have a good asset structure and are optimistic about their products and services. Usually large companies have more flexible access to their products. Product profits from sales to increase company value

Access owned by large companies makes large companies have advantages over small companies. The existence of such access makes large companies have higher potential to generate greater profits. Therefore, investors will be more interested in investing in large businesses, (Pradipa and Azizah 2015). 
The size of the company strengthens the influence of the capital structure on firm value

The results of this study indicate that the size of the company does not strengthen or weaken the influence of capital structure on firm value. The size of the company does not have an influence on the capital structure of the value of the company. This is because the size of the company is not a consideration for companies to add external funding sources. The size of a large company will not add to the company's capital structure. The size of large companies shows that companies have internal funding sources that come from large retained earnings, so companies can finance investments with funds collected, (Dewi and Sudiarta 2017).

The results of this study that are in accordance with the Pecking Order Theory are that companies are more likely to like funding that comes from internal rather than debt, so the size of the company has no influence on the relationship of the use of external relations. funding source with company value. Large companies will be more guaranteed to have easier access to get their capital resources to increase company value.

\section{CONCLUSIONS}

Based on the results of testing and discussion of this research can be concluded as follows: simultaneously the size of the company is able to moderate the relationship of asset structure and capital structure to the value of the company. While partially the size of the company only moderates the relationship of asset structure to firm value.

\section{BIBLIOGRAPHY}

Abidin, Zainal et al. 2014. Effect of Capital Structure, Dividend Policy and Size on Company Values. Journal of Management Insights, Vol.2 No.3 October 2014

Brigham, Eugene F, Houston.2011. Fundamentals of Financial Management. Edition 11. Jakarta: Erlangga 
Dewi, Sudiarta.2017. Effect of Profitability, Company Size, Asset Growth on the Sector of Capital and Corporate Value. E-Journal of Management of Unud. Vol.6 No.4,2017: 2222-2252

Dewi, Wirajaya.2013. Effect of capital structure, profitability and company size on firm value. E-accounting journal of Udayana University. ISSN: 23028556. Faculty of Economics, Uudayana University: Bali

Halim, Abdul. 2015. Business Financial Management. Bogor: Ghalia Indonesia.

Indriantoro, Supomo. 2002, Business Research Methodology, Second Print, Yogyakarta; BFEE UGM Publisher.

Kasmir.2010. Analysis of Financial Reports. Third edition. Jakarta: PT Raja. Grafindo Persada

Mandalika, Andri.2016. Effects of Asset Structure, Capital Structure, and Sales Growth on Company Values in Registered Public Companies

Jusup, Haryono.2011. Accounting Basics ar Ddi Indonesia Stock Exchange. Journal of Scientific Periodic Efficiency.16 (1): 207-218

Martono, Harjito.2005. Financial Management. Publisher Ekoisia: Yogyakarta

Nadzirah, Fridayana Yudiaatmaja, Wayan Cipta. 2016. Effect of Company Size and Profitability on Capital Structure. [online] Available: https:/ / www.e-jurnal.com/2014/1.Diakses24 November 2018.

Nyamasege, Dennis et al. 2014. Effect of Asset Structure on Value of a Firm: a Case of Companies Listed in the Nairobi Securities Exchange. [online] Available: https: / / scholar.google.co.id/scholar. Accessed December 31, 2018

Pradipta, Azizah.2016. Influence of Company Size, Accountability, Profitability and Liquidity on Extensive Requirements for Disclosure of Financial Statements. Journal of Administration and Business. Vol. 6, 2016. University of Brawijaya

Sartono, Agus.2012. Financial Management Theory and Application. Edition 4. Yogyakarta: BPFE.

Seftianne and Handayani, Ratih. (2011). Factors Affecting Structure

Capital in the Manufacturing Sector Public Company. Business and Accounting Journal Vol. 13, No. 1, April 2011, p. 39-56. 
Supami Wahyu Setiyowati dan Mardiana : Company Size Strengthens The Infuence of Asset Structure and Capital Structure on Firm Value

ilaban, Septika Soputri.2013. Influence of financial performance, capital structure, size of the company size of the company on the value of the company in the banking companies listed on the IDX. Faculty of Economics, University of North Sumatra: Medan

Soliha, Taswan.2012. Effects of Debt Policy on Company Values and Several Factors that Affect It. Journal of Business and Economics, Vol. 9, pp. 149163 